\title{
NOVE INTERPRETACIJE FLUVIALNIH SEDIMENTOV NA KRASU
}

\author{
Andrej Mihevc \\ Inštitut za raziskovanje krasa, Znanstvenoraziskovalni center SAZU \\ Titov trg 2, SI - 6230 Postojna, Slovenija \\ e-mail: andrej.mihevc@guest.arnes.si
}

Izvirni znanstveni članek

COBISS 1.01

\section{Izvleček}

Predstavljene so pomembne brezstrope jame s fluvialnimi sedimenti na Divaškem krasu, v Matarskem podolju in Podgorskem krasu. Opisana je njihova prostorska razprostranjenost ter odnos do obstoječih jam in kraškega površja ter njihov geomorfološki pomen. Sedimenti iz njih so bili analizirani in datirani z različnimi metodami. Največja starost sedimentov je bila ugotovljena v brezstropi jami v Črnotiškem kamnolomu. V njej so na steni ohranjeni fosilni ostanki jamske vodne živali Marifugia cavatica prekriti s 3,2-4,1 Ma starimi sedimenti.

Ključne besede: brezstropa jama, fluvialni sediment, geomorfologija, starost, kras, Kras

\section{NEW INTERPRETATIONS OF FLUVIAL SEDIMENTS FROM THE KRAS}

\begin{abstract}
Important unroofed caves with fluvial sediments from Divaški kras, Matarsko podolje and Podgorski kras are presented. Extend of the phenomena and relation to the existing caves and karst surface and geomorphological meaning of them are described. Sediments from them were analysed and dated with different methods. The largest age of the sediment was found in the unroofed cave excavated in Črnotiče quarry. In the cave wall fossil remains of stygobiont Marifugia cavatica were covered by 3.2-4.1 Ma old fluvial sediments.
\end{abstract}

Key words: unroofed cave, fluvial sediment, geomorphology, age, karst, Kras 


\section{UVOD}

Čeprav je večji del Krasa brez površinsko tekočih voda, so alohtoni fluvialni sedimenti, predvsem nekarbonatni prod in kremenčev pesek na njem dokaj pogosti. Najdemo jih $\mathrm{v}$ jamah in na površju. $Z$ razvojem proučevanja krasa so se interpretacije o njihovem izvoru in času nastanka predvsem pa o njihovem geomorfološkem pomenu precej spremenile.

Največ alohtonih fluvialnih sedimentov je $\mathrm{v}$ aktivnih ponornih jamah, pa tudi $\mathrm{v}$ jamah, ki leže vzdolž podzemnega toka Reke med Škocjanskimi jamami in izviri Timave. Podobni sedimenti so znani tudi iz drugih višje ležečih, danes neaktivnih jam. Najdemo jih tudi na kraškem površju v okolici ponorov na robu Krasa. Zaradi lege v bližini površinskega ali podzemnega toka rek ponikalnic so te sedimente raziskovalci krasa obravnavali kot pokazatelja lastnosti vodnega toka, za dokazovanje izvornega območja ponikalnic pa tudi kot indikator klimatskih sprememb (Melik 1960; Roglič 1957; Gams 1962a, 1962b; Kranjc 1986, 1989).

Manj jasna pa so bila po obsegu manjša površinska nahajališča alohtonih fluvialnih sedimentov, $v$ različnih geomorfoloških legah po celotni planoti, $v$ dnu vrtač, udornic, na uravnanem površju in v pobočjih hribov v relativno visoki legi nad planoto Krasa. O takšnih alogenih sedimentih, predvsem kremenovih peskih in prodih so poročali Pleničar (1954), Melik (1955), D’Ambrosi (1965), Radinja (1967, 1985). Pripisovali so jih površinskim rekam, ki naj bi tekle po površju krasa. Sedimenti naj bi bili odloženi na površju, nekateri pa kasneje tudi lokalno preneseni ali sprani v različne kraške žepe, kotanje brezna ali jame, kjer so se v zaščitenih legah ohranili. S temi sedimenti so dokazovali površinski tok rek, zato so tudi nekatere reliefne oblike $\mathrm{v}$ krasu opisali kot suhe doline. V okviru splošno prevladujočega cikličnega modela pa so ti sedimenti služili tudi kot dokaz za obstoj posebne predkraške faze v razvoju reliefa.

Ta pogled je nekoliko modificirala klimatska geomorfologija (Roglič 1957; Radinja 1972), ki je poudarjala pomen klime za geomorfne procese. Nekateri sedimenti, na primer rdeče prsti naj bi nastali kot posledica specifičnega preperevanja $\mathrm{v}$ topli pliocenski klimi, grobi klastični sedimenti, pesek, prod in naplavljanje sedimentov na kras pa $\mathrm{v}$ hladnih pleistocenskih klimah. Iz vrste sedimentov pa sklepajo na čas odlaganja na kras (Melik 1955; Gospodarič 1987; Habič 1992).

Geomorfološka analiza oblik ponornega kontaktnega krasa je pokazala na skupine in sosledja reliefnih oblik ob robu Krasa ter na zakonitosti prenašanja fluvialnih sedimentov na kras (Mihevc 1991). Še pomembnejše za proučevanje alohtonih sedimentov na Krasu pa je bilo podrobno geomorfološko in speleološko proučevanje Divaškega krasa (Mihevc 2001), ki je odkrilo veliko število nekdanjih jam, nad katerimi je kraška denudacija že odstranila vso kamnino. Imenovali smo jih brezstrope jame (Mihevc 1996). Brezstrope jame so bile povečini zapolnjene s sedimenti, največ $\mathrm{z}$ alohtoni kremenovi peski in prodi. Prav taki sedimenti so bili v preteklosti napačno interpretirani in so služili za dokaz za površinski tek rek po površju Krasa.

Kartiranje in proučevanje brezstropih jam in sedimentov v njih v okolici Sežane, na Divaškem in Podgorskem krasu, Matarskem podolju in drugod, je omogočilo nov pogled na razvoj Krasa (Mihevc 2007), obenem pa je omogočilo tudi datiranje reliefnih oblik in 
sedimentov z različnimi metodami (Mihevc 1996, 2001; Bosak et. al., 1999, 2003, 2004).

Rezultati raziskav so pokazali nekaj splošnih zakonitosti v zvezi s speleogenezo brezstropih jam, odložitvijo alohtonih sedimentov v njih, denudacijo kraškega površja ter njihovo starostjo. Rezultati posameznih raziskav so bili že objavljeni v več člankih, tu pa na kratko povzemam nekatere najpomembnejše primere in ugotovitve.

\section{BREZSTROPE JAME V DIVAŠKEM KRASU}

Pri pripravah na gradnjo avtoceste so zaznali na uravnanem površju vzhodno od Povirja, v višinah med 398 in $400 \mathrm{~m}$, v osi cestišča podolgovato, do $10 \mathrm{~m}$ široko območje s slabšimi geomehanskimi lastnostmi. Ko so gradbeniki odstranili rušo in vrhnji sloj prsti, rdeče ilovice in različne sedimente, je postalo jasno, da je bila to stara, s sedimenti zapolnjena jama. Strop nad jamo pa je denudacija že odstranila.

Brezstropa jama je bila pred deli na trasi komaj zaznavna kot plitva uleknina. Na letalskih posnetkih infrardečega dela spektra je dobro vidna kot pas svetlejših, to je toplejših tal, del jame pa označuje pas grmovja, ki se je zarasel na debeli prsti. Na kartah franciscejskega katastra pa izstopa kot ozka podolgovata njiva sredi pašnika.

Brezstropa jama pri Povirju (Mihevc 1996) je ostanek nekdanje jame večje jame, ki je bila v večjem delu široka okrog $6 \mathrm{~m}$, debelina izkopanega sedimenta večjem delu rova je bila 3 - 4 m, vendar izkop ni nikjer dosegel živoskalnih tal rova. V SZ delu se je še ohranil strop, debel je bil le še okrog $1 \mathrm{~m}$.

Stene izkopanega rova so bile navpične, mestoma celo previsne. Na stenah so se ohranili sledovi oblikovanja v jamskem okolju, sledovi korozijskega oblikovanja ob stiku s sedimentom ter sledovi mehanskega in korozijskega preoblikovanja v subkutani coni krasa. Od jamskih oblik so bile najbolj izrazite stenske zajede, to so v prečnem prerezu polkrožni žlebovi, ki nastanejo v višini vodnega toka. Nagnjene so bile do $3^{\circ}$ od SZ proti JV. Fasete so bile na več mestih, vendar so bile le na dveh dobro ohranjene. Poprečna velikost faset je bila 2 - $3 \mathrm{~cm}$, kazale pa so smer toka proti JV. Takšni fasete nastanejo v vodnem toku s hitrostjo okrog $1 \mathrm{~ms}^{-1}$.

Na nekaj mestih v rovu je površino skale prekrila siga, ter jo tako popolnoma ohranila, medtem ko je korozija v neposredni soseščini odstranila 5-20 mm površinskega sloja kamnine. Na nekaj mestih so bili v rovu tudi sledovi močnejšega vertikalnega prenikanja in z njim povezanega spiranja, kar se je izražalo kot prodor rjave površinske prsti v jamski sediment. Na skali so bile tu močnejše korozijske poškodbe.

$\mathrm{V}$ rovu so bile opazne poškodbe sten, ki jih je povzročilo zniževanje oziroma približevanje površja oziroma epikraške cone. V rovu pa so ti pojavi izraženi kot večja gostota razpok in korozijsko razširjenih, z rdečo ilovico zapolnjenih razpok v vrhnjem delu sten rova do okrog $1,5 \mathrm{~m}$ pod površjem.

Jamski rov je bil v celoti zapolnjen s sedimenti. Na površju je bila okrog $10 \mathrm{~cm}$ debela plast rjave prsti. Navzdol je sledila rdečkasta, do $1 \mathrm{~m}$ debela plast preperelega sedimenta $\mathrm{s}$ posameznimi nekarbonatnimi prodniki. Brez ostrega prehoda se je nadaljevala v rumenorjavo obarvane plasti ilovice, peska in proda. 
Prodniki iz flišnega peščenjaka in apnenca so se v jami ohranili le pod sigovimi kopami. $\mathrm{V}$ večjem delu jame so prodniki iz flišnega peščenjaka ležali v plasti kremenčevega peska. Ko so se posušili, so tudi ti razpokali in razpadli v kremenčev pesek. Največji prodnik je imel daljšo os dolgo $25 \mathrm{~cm}$.

Slika 1: Brezstropa jama pri Povirju potem, ko so iz nje izkopali alohtone fluvialne sedimente. Figure 1: Unroofed cave at village Povir after allogenous fluvial sediments were excavated.

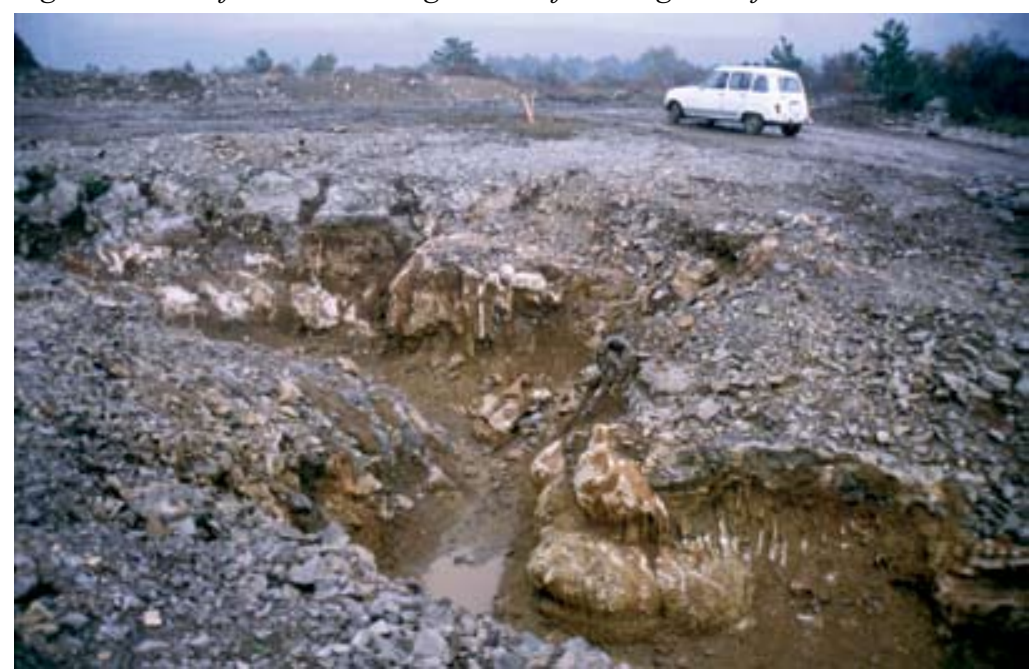

Peski so se pojavljali v obliki lečastih teles ali lamel v ilovici ali samostojno. V zgornjem delu profila sedimentov je njihova barva prehajala v rdečerjavo (2,5YR 4/8) barvo. Enako je bilo moč opazovati peske z rumenorjave barve (10YR 5/6), ki so ob steni rova spremenili barvo v rdeče rjavo, čeprav je šlo nedvomno za iste plasti.

Mineraloška analiza peskov je pokazala dokaj enako sestavo, večino so tvorila silikatna zrna (97 \% ali več), ostali minerali so le v sledeh. Zrna so slabo zaobljena in se po zaobljenosti ne ločijo od zrn peska v flišnih prodnikih. Peski se ločijo po barvi, ta pa izvira le iz površinske obarvanosti, rumeno barvo jim daje goethit, rdečo pa hematit, minerala, ki sta bila zastopana v sledovih (Mihevc in Zupan Hajna 1996).

Ilovice (meljne gline s primesmi) so bile $\mathrm{v}$ jami pomešane s plastmi ali lečami peskov, pa tudi proda. Posebnost ilovic so močno povite sedimentacijske strukture, kar kaže na močno pregnetenja plastičnih sedimentov v času po odložitvi. Prevladujoča barva ilovic je bila v spodnjem delu profila rumenkastorjava (10YR 5/8), v gornjem delu in ob steni pa je spremenila barvo v rdečerjavo barvo. Po mineraloški sestavi med obema vrstama ilovice ni bilo bistvenih razlik. V njej prevladujejo kremen (nad $90 \%$ ) in illit.

Siga se je vjami ohranila v obliki skorij, masivnih sigovih kop, prosto stoječih stalagmitov, v sedimentu pa tudi do pol metra dolgi stalaktiti. Največ stare sige je bilo v SZ delu jame. Očitno smo bili v tem delu rova bliže njegovemu nekdanjemu stropu. Tu se je ohranilo nekaj masivnih kop, nekaj zaves, ter celo kapniški steber, ki pa ni več imel stropa nad seboj. 
Vzorec sige s tega mesta je bil datiran $\mathrm{z}^{234} \mathrm{Th} /{ }^{230} \mathrm{U}$ metodo. Analiza pa je pokazala, da starost sige presega $350 \mathrm{Ka}$, kolikor je meja te metode. Starost jame je seveda veliko večja. $\mathrm{Ob}$ predpostavljeni debelini denudiranega stropa $100 \mathrm{~m}$ in predpostavljeni denudacijski stopnji 20-50 m/Ma bi bila jama stara 2-5 Ma.

Slika 2: Jame in brezstrope jame na Divaškem krasu. Legenda: 1. obris pomembnih aktivnih jam, 2. obris Divaške jame, 3. Brezstrope jame, 4. pomembne brezstrope jame: A brezstropa jama pri Povirju, B brezstropa jama v Divaškem Radvanju, nadaljevanje Divaške jame, C brezstropa jama v Lipovih dolinah, 5. višinske kote površja, 6. višine gladine Reke vjamah, 7. površinski tok Reke, 8. verjetna smer podzemnega pretakanja, 9. obris Divače.

Figure 2: Caves and unroofed caves of the Divaški kras area. Legend: 1. outline of the important active caves, 2. outline of the cave Divaška jama, 3. unroofed caves, 4. important unroofed caves: A unroofed cave at Povir, B unroofed cave in doline Divaški Radvanj, continuation of cave Divaška jama, C unroofed cave in Lipove doline, 5. altitude of the surface, 6. altitude of river Reka in the caves, 7. surface flow of river Reka, 8. presumed direction of the underground flow, 9. outline of the village Divača.

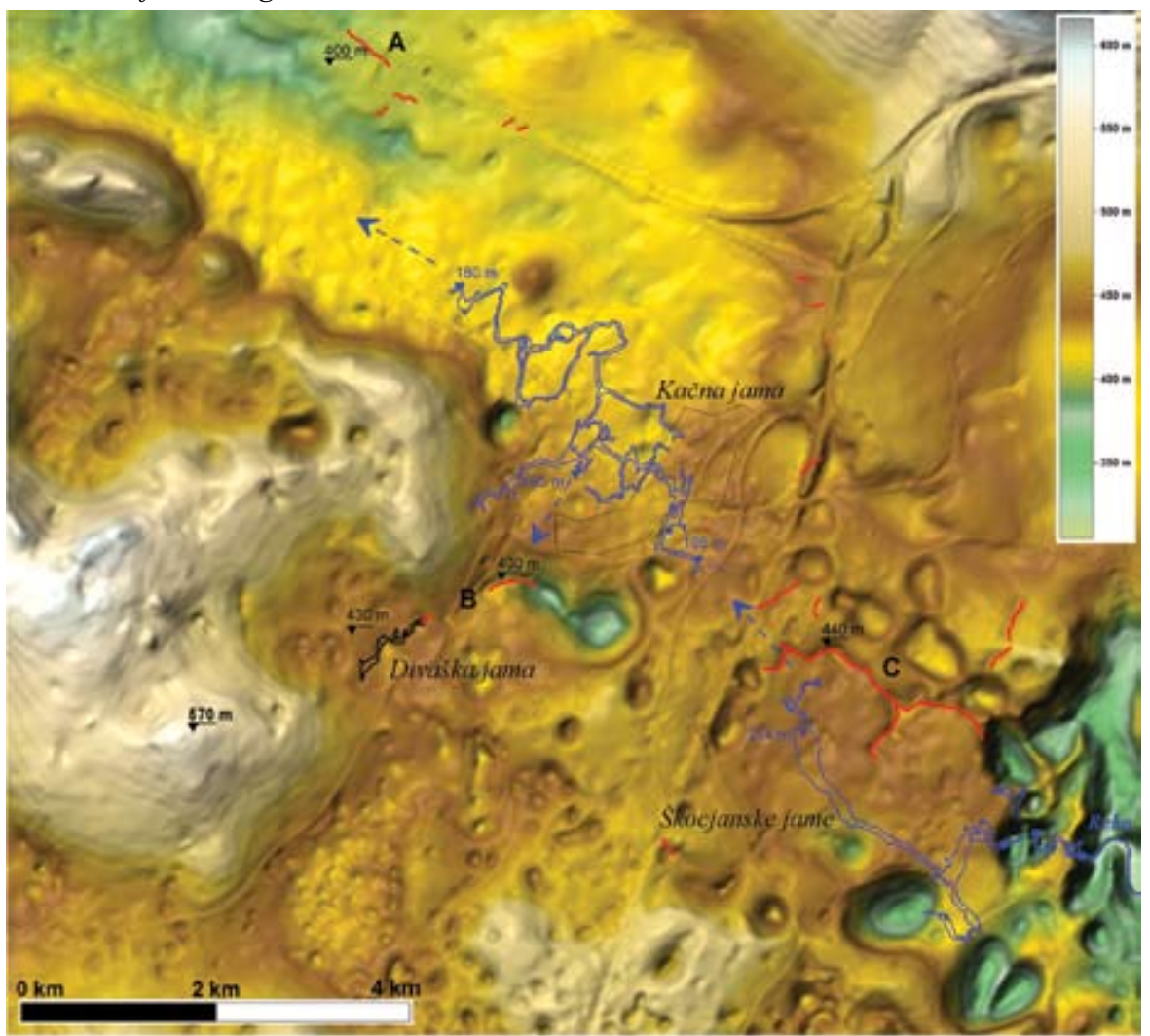
1. 2 . N
3. 4.ABC $5.4^{400=} 6.2^{14 m} 7 . \leftarrow$
8. $\lessdot-9$. 
Slika 3: Nastanek brezstrope jame. Ideali-zirana slika je na osnovi primerov brezstropih jam z Divaškega krasa. Transformacija je predstavljena v treh stop-njah: a: jamski rov je nastal globoko pod površjem. V rovu so se izmenično usedali siga in alohtoni fluvialni sedimenti, ki jih je vjamo prinašala ponikalnica. b: površje se je približalo jami. Pobočje s strani je prerezalo jamo zato so tam jamski sedimenti že na površju. c: po razpadu stropa se v površju krasa oblikuje podolgovata plitva uleknina. V njej so razgaljeni alohtoni fluvialni sedimenti, nekaj blokov apnenca in sige. Brezstropa jama se končuje s strmim robom, nad katerim se nadaljuje površje krasa.

Figure 3: Formation of the unroofed caves. The idealised drawing is representing the actual cases of unroofed or partly unroofed caves from the Divača karst. The transformation is here presented in three stages: a: cave passage was formed deep below the surface. There was alternation of sedimentation of flowstone and allogenic sediments from underground river. $b$ : surface approached the cave. At the side the slope cut passage and exposed the cave sediments to the surface. c: after disintegration of the ceiling from the top oblong depression formed. Allochtonous sediments and flowstone are exposed on the surface. The unroofed cave ends with steep limestone wall or slope from where the karst surface continues.
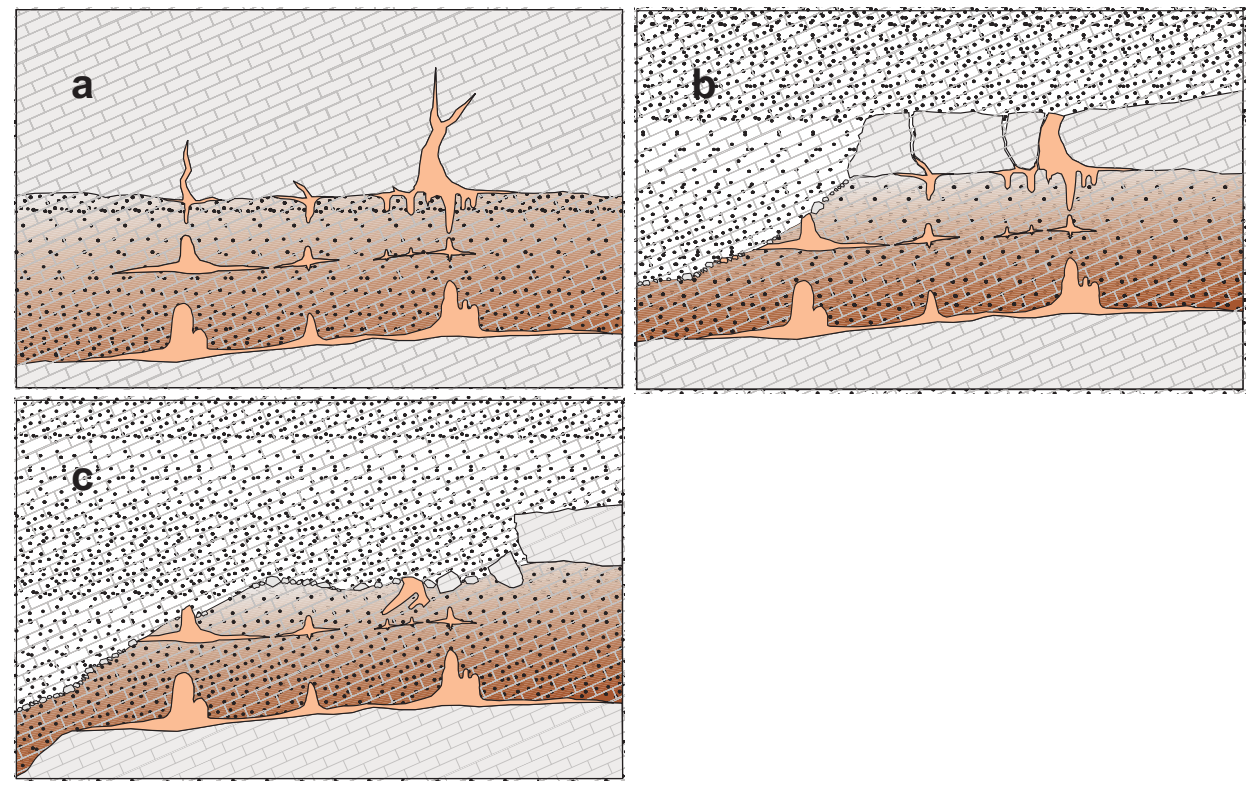

Podobni sedimenti, kakršni so bili najdeni v Brezstropi jami so bili ob gradnji avtoceste najdeni še na več drugih mestih. Pri sedimentih, v vseh primerih je šlo za jamske sedimente, se je pokazalo nekaj izrazitih skupnih potez, pa tudi nekaj razlik, ki so posledica individualnega razvoja vsake jame. Izrazite razlike so pojav sige, podornih skal ali ostrorobega grušča na alohtonih sedimentih, kar kaže način, kako so se posamezne jame odprle proti površju. Ponekod so bili najdeni sedimenti velikosti od gline, melja, peska, do proda, drugod pa le ene od frakcij. To pa odraža lastnosti porečij jamskih ponikalnic, bližine ponorov, lege dela jame $\mathrm{v}$ jamskem sistemu in časa $\mathrm{v}$ katerem so nastale. 
Na Divaškem krasu je bilo proučenih 17 večjih brezstropih jam. Njihova skupna dolžina na površju (v vseh so bili tudi alohtoni sedimenti) je $2900 \mathrm{~m}$.

Največja med njimi je brezstropa jama v Lipovih dolinah. Leži v višini okrog $450 \mathrm{~m}$ in je morfološko zelo izrazit, $1800 \mathrm{~m}$ dolg niz podolgovatih, razpotegnjenim vrtačam podobnih depresij, ki prehajajo ena v drugo brez vmesnih višjih pragov. Njihovo dno je vseskozi okrog 5 - $10 \mathrm{~m}$ pod višino ostalega površja, široke pa so $20-30 \mathrm{~m}$. V njih je prod pisanega roženca ter rumenorjave peščene ilovice ter masivne sige. Po grobi oceni je v denudirani jami še sedaj ohranjenih okrog $45.000 \mathrm{~m}^{3}$ jamskih sedimentov (Mihevc 2001, 145).

Za razumevanje razvoja krasa je pomembna tudi s sedimenti zapolnjena jama, ki jo prerežejo pobočja Gorenjskega Radvanja. Po legi, dimenzijah ter tipu sedimentov je ta denudirana jama nadaljevanje Divaške jame od vhodnega dela proti severovzhodu. Podobni sedimenti in enaka nadmorska višina ter bližina postavlja Divaško jamo in brezstropo jamo v Radvanju v Radvanju ter Brezstropo jamo pri Povirju, v isti časovni okvir.

\section{BREZSTROPE JAME IN SEDIMENTI V PODGORSKEM KRASU}

Ob J robu Krasa leži nekaj nižja planota Podgorskega krasa. Zgrajena je iz paleogenskih apnencev z vmesnimi luskami fliša. Večji del planote se odteka kraško v izvire Rižane, Osapske reke in Boljunca, ki leže v višini 50 - $100 \mathrm{~m}$.

Pri geomorfološkem kartiranju smo na Petrinjskem krasu severno od kamnolomoma Črnotiče na približno $1 \mathrm{~km}^{2}$ površja določili 14 brezstropih jam v skupni dolžini okrog 900 $\mathrm{m}$. Vse so zapolnjene različnimi sedimenti. V reliefu so izražene kot plitve, 4-8 m široke podolgovate uleknine. Podobna gostota brezstropih jam ter podobne oblike na površju se nadaljuje v Črnotiškem kamnolomu. Tu smo lahko spremljali izkopavanje velike, $180 \mathrm{~m}$ dolge s sedimenti zapolnjene jame. Glavni rov jame je imel dimenzije okrog 15 x 15 m, v spodnjem delu je bil zapolnjen s plastmi prodov peskov in ilovic, preko katerih so se odložile debele plasti sige. V delu jame so se odložili tudi avtohtoni grušči med njimi so bili ostanki kosti velikih sesalcev pleistocenske starosti (Aguilar 1998).

Manjši stranski rov je od 4-8 m širok, od dna izkopa v nadmorski višini $424 \mathrm{~m}$ do površja pa visok $17 \mathrm{~m}$. Stene rova so v spodnjem delu fasetirane. Fasete so dolge okrog $30 \mathrm{~cm}$ ter kažejo na počasen vodni tok, ki pa je pri velikem profilu rova pomenil pretok več $\mathrm{m}^{3} \mathrm{~s}^{-1}$. Smer toka je bila proti JV.

Rov je bil v celoti zasut s sedimenti. V spodnjem delu zapolnitve so pasovite gline v izmenjavi s kremenovimi peski. V zgornjem delu profila prevladujejo kremenčevi peski in prodniki iz eocenskega flišnega peščenjaka. Po odložitvi teh sedimentov je nad fluvialnimi sedimenti še 7 m debela plast sige in stalagmitov. Kraška denudacija je odstranila kamnino nad jamo pa tudi del sedimentov, zato sega siga že na površje, ki je v nadmorski višini $441 \mathrm{~m}$.

V profilu smo našli na fasetirano steno zasute jame pritrjene drobne cevke, podobne cevkam recentnega jamska sladkovodnega črva Marifugia cavatica, ki živi v mirnih pod- 
zemnih vodah (Mihevc, 2000). Njena ličinka se pritrdi in nato obda s trdno apnenčasto cevko. Žival gradi cevko sprva pritrjeno na steno jamskega rova, nato pa raste cevka pravokotno na steno. Pogosti so odlomljeni deli cevk v pesku kraških izvirov. Njene cevke najdemo tudi v bližnjih izvirih Rižane in Osapske reke. Poleg tega smo našli v profilu tudi ostanke zob različnih vretenčarjev, sesalcev in rib, ki pripadajo paleontološki bioconi MN15 - 16, oziroma so stari 3,2 - 4,1 Ma (Horaček et. al. 2007).

Slika 4: Pogled na s sedimenti zapolnjeno brezstropo jamo v Črnotiškem kamnolomu. Vzgornjem delu zapolnitve so to sige, $v$ spodnjem pa fluvialni sedimenti. Na desni fasetirani steni je označeno mesto (M), kjer so ohranjene cevčice jamske vodne živali Marifugia cavatica.

Figure 4: View to sediment filled unroofed cave in the Črnotice quarry. Upper part is filled with flowstone and lower with fluvial sediments. The sign $(M)$ is marking the scalloped wall place where tubes of stigobiont Marifugia cavatica are preserved.

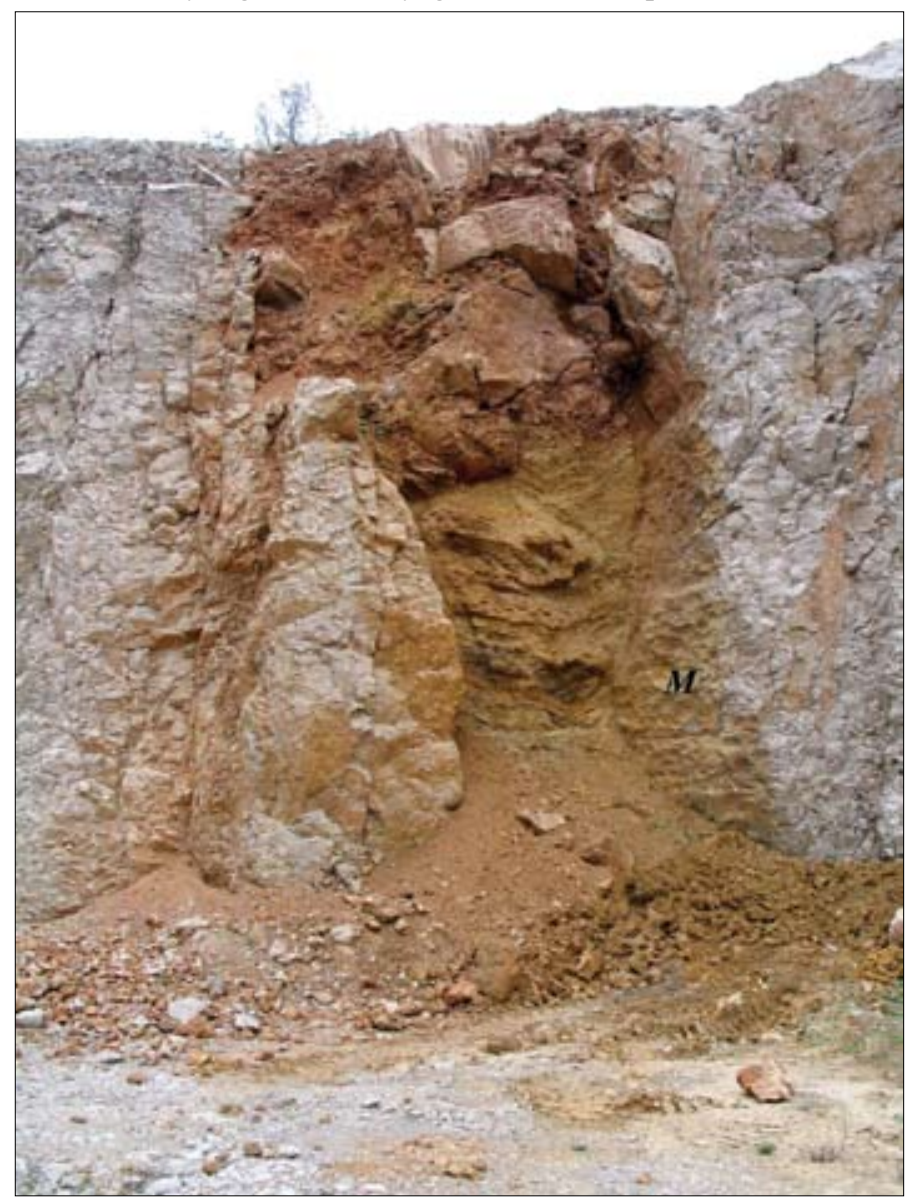




\section{BREZSTROPE JAME IN DATACIJE SEDIMENTOV V MATARSKEM PODOLJU}

Matarsko podolje je $25 \mathrm{~km}$ dolg in 2-5 km širok kraški ravnik, ki je nagnjen proti SZ. Z Brkinov, ki leže SV od njega, priteka na kras 17 večjih potokov, ki so si v rob ravnika vrezali različno globoke slepe doline. $\mathrm{V}$ njih in $\mathrm{v}$ jamah $\mathrm{v}$ katere potoki ponikajo, najdemo sedimente, ki izvirajo iz flišnih kamnin. Podobne sedimente pa najdemo tudi $v$ jamah in na površju Matarskega podolja.

Slika 5: Prečniprerez dela Brkinovin Matarskega podolja z lego ponikalnicev slepi dolini ter legami Račiške pečine, Ulice pečine in brezstrope jame. Legenda: 1. fliš, 2. apnenec, 3. ponikalnica.

Figure 5: Cross section across Brkini hills and Matarsko podolje with position of the blind valley and sinking stream and caves Račiška pečina and Ulica pečina with unroofed cave. Legend: 1. flysch, 2. limestone, 3. sinking stream.

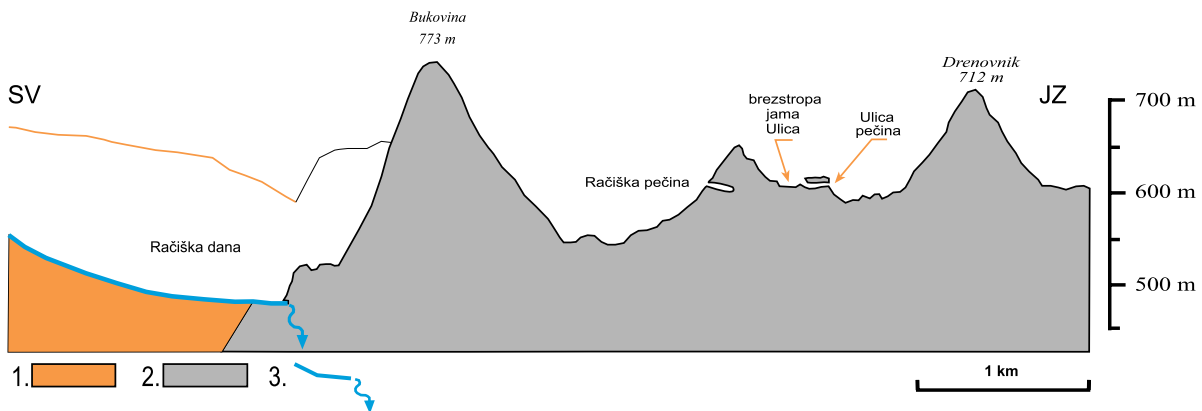

V JV delu podolja, je v bližini Račic je v nadmorski višini 690 m, 304 m dolga globoka Račiška pečina. Jama je oblikovana $\mathrm{v}$ debeloskladovitih krednih apnencih, ki vpadajo pod kotom okrog $30^{\circ}$ proti SV. Jama je ostanek nekdanjega večjega jamskega spleta, ki se je ohranil kot enostaven okrog $10 \mathrm{~m}$ širok in do $10 \mathrm{~m}$ visok rov, ki se od vhoda blago spušča proti $\mathrm{J}$ in se konča s podorom ob močnem prelomu. Stene in strop rova so v večjem delu živoskalne, na njih so vidni sledovi epifreatičnega in paragenetskega oblikovanja.

$\mathrm{V}$ jami smo proučili $20 \mathrm{~m}$ dolgo in 5,5 $\mathrm{m}$ debelo sedimentacijsko sekvenco plastovite sige z vmesnimi sloji alohtonih peskov in rdečih ilovic, redkimi podornimi skalami in jasno izraženimi hiatusi v sedimentaciji (Horaček et al. 2007).

Spodnji del profila sestavljajo debeloplastovite sige s plastmi rdečih ilovic. Sledijo tanko plastovite sige $\mathrm{z}$ nekaj podornimi skalami. Za skalami so se odložile plasti ilovic in kremenovih peskov v katerih smo našli ostanke fosilne favne. Paleontološke analize so pokazale, da ostanki, določljivi so bili le zobje malih sesalcev, pripadajo paleontološki bioconi MN 17 in so stari 1,8 do 2,4 Ma. Nad njimi se je odložila plastovita siga, nato pa plast grušča z ostanki kosti jamskega medveda. Grušč prekriva še $40 \mathrm{~cm}$ debela holocenska siga s plastmi oglja antropogenega izvora. 
Paleomagnetne raziskave profila, ki so se oprle na paleontološko datirano plast so pokazale, da je starost sige v spodnjem delu profila 3,2 Ma. Šele pod temi plastmi pa so bile odložene alohtoni sedimenti, ki jih je $\mathrm{v}$ jamo prinesla ponikalnica $\mathrm{v}$ freatičnih ali epifreatični pogojih.

V enaki nadmorski višini je v bližini še več večjih vodoravnih jam, ostankov nekdanjega velikega jamskega sistema. Največja med njimi je $1 \mathrm{~km}$ oddaljena Ulica pečina. Jamo sestavlja enostaven $120 \mathrm{~m}$ dolg rov $\mathrm{z}$ dvema vhodoma in paragenetsko uravnanim stropom, katerega debelina je največ $10 \mathrm{~m}$. Večji del rova je bil zapolnjen $\mathrm{z}$ alohtonimi sedimenti, ki so v srednjem delu jame sprani v nižje votline. Ta del rova je visok okrog $20 \mathrm{~m}$ in širok $15 \mathrm{~m}$. Najbolj opazna značilnost jame pa je v višini 488 - 490 m paragenetsko uravnan strop.

Slika 6: Tloris in prečni prerez Ulice pečine in brezstrope jame Ulica.

Figure 6: Plan and profile of cave Ulica pečina and unroofed cave Ulica.

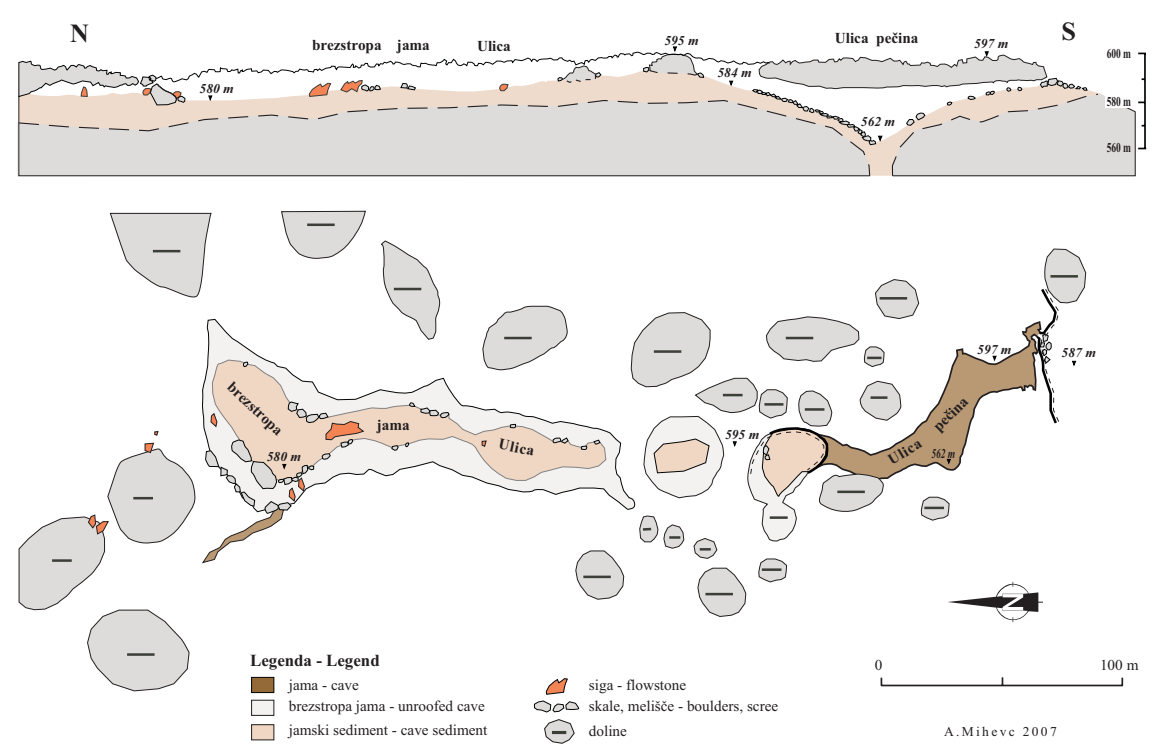

Površje nad jamo je morfološko močno razčlenjeno. Škraplje so globoke do $3 \mathrm{~m}$, na površju pa je tudi nekaj manjših vrtač. Če primerjamo to razčlenjeno površje z jamskim stropom, vidimo, da je strop veliko bolj uravnan. To kaže, da jame še ni zajela korozijska fronta epikraške cone.

Od jamskega vhoda se proti severu nadaljuje $250 \mathrm{~m}$ dolga brezstropa jama. Ta jama je $\mathrm{v}$ večjem delu v reliefu izražena kot do $10 \mathrm{~m}$ globok in $30 \mathrm{~m}$ širok jarek. V njem so na več mestih ostanki masivne sige ter do $5 \mathrm{~m}$ debele plasti kremenčevega peska. Brezstropa jama se nadaljuje $\mathrm{v} 40 \mathrm{~m}$ dolgi, z masivno sigo zapolnjeni jami, katere strop pa je le debele še do $3 \mathrm{~m}$. 
Ulica pečina (Ulica je toponim, ki označuje površje kje leži brezstropa jama, S od Ulice pečine) in njeno nadaljevanje brezstropa jama Ulica dobro ilustrirata prehod iz jame v brezstropo jamo. oziroma delovanje korozijske fronte, ki znižuje površje, obenem pa oblikuje različne kraške oblike ter tako povezuje površinsko in podzemno kraško morfologijo.

Slika 7: Pogled iz brezstrope jame Ulica na severni vhod v Ulico pečino.

Figure 7: View from the unroofed cave Ulica into the N entrance to Ulica pečina.

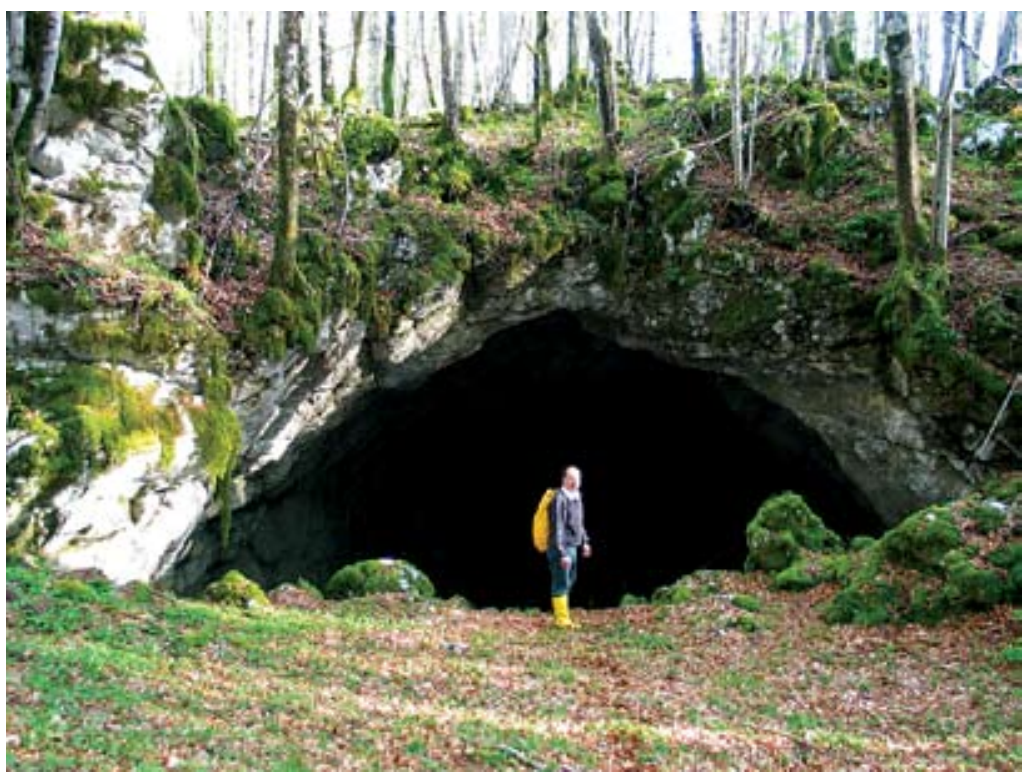

\section{SKLEP}

Odkritje številnih velikih, s fluvialnimi sedimenti zapolnjenih brezstropih jam na Krasu, v Matarskem podolju in Podgorskem krasu, zahteva novo interpretacijo nahajališč fluvialnih sedimentov na kraškem površju, s tem pa tudi drugačno interpretacijo geomorfološkega razvoja teh kraških površij. Najpomembnejše so naslednje ugotovitve:

- Brezstropa jama je kraški pojav, ki nastane, ko površje zaradi denudacije prereže podzemno votlino. Na recentnem površju se tako pojavi preoblikovana, brezstropa jama, pa tudi avtohtoni in alohtoni sedimenti, ki so se nekoč odložili v jamskem okolju.

- Alohtoni fluvialni sedimenti na površju Krasa, razen tistih, ki jih najdemo v kontekstu površinskih oblik kontaktnega krasa, v glavnem izvirajo iz brezstropih jam.

- Brezstrope jame so nastale z denudacijo najstarejših jam, mlajše jame leže niže, globlje pod površjem.

- Ker so te jame najstarejši kraški element v pokrajini, njihov pojav izključuje obstoj starejših reliefnih oblik, saj je te denudacija že v celoti odstranila. 
- V brezstropih jamah so različni alohtoni sedimenti, kar kaže na zapolnjevanje iz različnih izvornih območij oziroma na drugačno paleogeografsko podobo nekdanjega reliefa.

- S pomočjo geomorfološke primerjalne metode, paleomagnetne in paleontološke datacijske metode smo datirali starost sedimentov v brezstropih jamah na $2-6 \mathrm{M}$ let.

- Pomembna je tudi najdba fosiliziranih, na steno brezstrope jame pritrjenih cevčic jamske živali Marifugija cavatica, starih 3,2-4,1 Ma. Fosili dokazujejo, da od takrat razvoj krasa ni bil nikoli prekinjen. Kažejo tudi na tedanje paleokraške pogoje ter obstoj krasa še pred tem, saj je živalska vrsta potrebovala čas za prilagoditev na življenje v jamah.

\section{Viri in literatura}

Aguilar, J.P., Crochet, J.Y., Krivic, B., Marandat, B. Michaux, J., Mihevc, A., Sigé, B., Šebela, S. 1998: Pleistocene small mammals from some karstic fillings of Slovenia - preliminary results. Acta carsologica 27/2. Ljubljana.

Bosak, P. Mihevc A., Pruner P., Melka K., Venhodova D., Langrova A. 1999: Cave fill in the Črnotiče quarry, SW Slovenia: palaeomagnetic, mineralogical and geochemical study. Acta carsologica 28/2. Ljubljana.

Bosák, P. Mihevc, A., Pruner, P. 2004: Geomorphological evolution of the Podgorski Karst, SW Slovenia: contribution of magnetostratigraphic research of the Črnotiče II site with Marifugia sp. Acta carsologica 33/1. Ljubljana.

Bosák, P., Pruner, P., Mihevc, A., Zupan Hajna, N., Horáček, J., Kadlec, J., Man, O., Schnabl, P. 2004: Račiška pečina. 12th International Karstological School, Classical Karst - Dating of Cave Sediments, Postojna. Guide booklet for the excursions and abstracts of presentations. Postojna.

D’Ambrosi, C., Legnani, F. 1965: Sul problema delle sabbie silicee del carso di Trieste. Boll. Della Societa Adriatica di scienze LIII. Trieste.

Gams, I. 1962a: Slepe doline v Sloveniji. Geografski zbornik 7. Ljubljana.

Gams, I. 1962b: Meritve korozijske intenzitete v Sloveniji in njihov pomen za geomorfologijo, Geografski vestnik 34. Ljubljana.

Gospodarič, R. 1987: Geocronology of Quaternary Karst Processes in the Karst of NW Yugoslavia. INQUA 87, Programme with abstracts.

Habič, P. 1992: Les phenomenes paleokarstiques du karst Alpin et Dinarique en Slovenie. V: Karst et evolutions climatiques. Bordeaux.

Horáček, I., Mihevc, A., Zupan Hajna, N., Pruner, P., Bosák, P. 2007: Fossil vertebrates and paleomagnetism update one of the earlier stages of cave evolution in the Classical karst, Slovenia: Pliocene of Črnotiče II site and Račiška pečina. Acta carsologica 36/3. Ljubljana.

Kranjc, A. 1986: Transport rečnih sedimentov skozi kraško podzemljena primeru Škocjanskih jam. Acta carsologica, 14/15. Ljubljana

Kranjc, A., 1989: Recent fluvial cave sediments, their origin and role in speleogenesis. Ljubljana.

Melik, A. 1955: Kraška polja Slovenije v pleistocenu. Dela Inštituta za geografijo SAZU, 3. Ljubljana. 
Melik, A. 1960: Primorska Slovenija. Slovenska matica. Ljubljana

Mihevc, A. 1991: Morfološke značilnosti ponornega kontaktnega krasa v Sloveniji. Geografski vestnik 63. Ljubljana.

Mihevc, A. 1994: Contact Karst of Brkini Hills. Acta carsologica 23. Ljubljana.

Mihevc, A. 1996: Brezstropa jama pri Povirju. Naše jame 38. Ljubljana.

Mihevc, A. 1999: The caves and the karst surface-case study from Kras, Slovenia. Etudes de géographie physique, suppl. XXVIII, Colloque européen-Karst 99. Mende.

Mihevc, A. 2000: Fosilne cevke iz brezstrope jame - verjetno najstarejši ostanki jamskega cevkarja Marifugia (Annelida: Polychaeta). Acta Carsologica 29/2. Ljubljana.

Mihevc, A. 2001: Speleogeneza Divaškega krasa. Ljubljana.

Mihevc, A. 2007: The age of karst relief in West Slovenia. Acta carsologica 36/1. Ljubljana.

Mihevc A., Zupan, N.1996: Clastic sediments from dolines and caves on the route of highway at Divača. Acta Carsologica 25. Ljubljana

Pleničar, M. 1954: Vrnik. Proteus XVII. Ljubljana

Radinja, D., 1967: Vremska dolina in Divaški kras. Problematika kraške morfogeneze. Geografski zbornik 10. Ljubljana.

Radinja, D., 1972: Zakrasevanje v Sloveniji v luči celotnega morfogenetskega razvoja. Geografski zbornik 13. Ljubljana.

Radinja, D., 1985: Kras v luči fosilne fluvialne akumulacije. Acta carsologica 14-15. Ljubljana.

Roglič, J., 1957: Zaravni u vapnencima. Geografski glasnik 19. Zagreb.

\section{NEW INTERPRETATIONS OF FLUVIAL SEDIMENTS FROM THE KRAS}

\section{Summary}

Discovery of numerous large unroofed caves filled with fluvial sediments on the plateau Kras, leveled surface of Matarsko podolje and on Podgorski kras demands new interpretation of the fluvial sediments on the karst surface and also new interpretation of geomorphic evolution of this karst surfaces. The most important are following findings:

- Unroofed cave is a karst phenomena formed when the surface because of karst denudation cuts the underground cavity. On the recent surface reshaped, unroofed cave is formed and allochtonous fluvial sediments, which were deposited in cave environment, appear.

- Allochtonous fluvial sediments on the surface of the Kras, except those that are in the context of the surface relief forms of contact karst, mare mainly derived from unroofed cave.

- Unroofed caves were formed with by denudation of the oldest caves; younger caves are deeper below the surface.

- Because the unroofed caves are the oldest karst element in the landscape their existence excludes the older, for instance pre-karst relief features, which were already removed by denudation. 
- There are different sediments exposed in unroofed caves which indicate infilling from different source areas and different paleogeography of the former surface.

- With the use of geomorphologic comparative method, palaeomagnetic and paleontologic dating methods the sediments from unroofed caves were dated to $2-6 \mathrm{Ma}$.

- Important is also the find of fossilized, on the wall of the unroofed cave attached tubes of stigobiont Marifugija cavatica dated to 3,2-4,1 Ma. They indicate that since that time karst evolution in the area was never interrupted. It also shows former conditions in karst and proves the existence of karst long before that, because the animal species needed time to adapt to life in cave environment. 